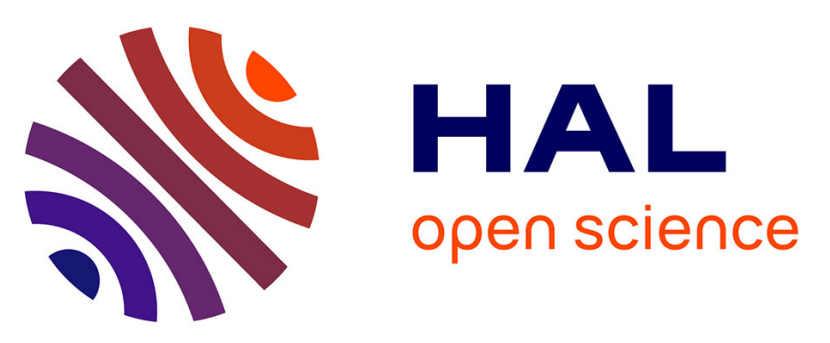

\title{
Pollen and nectar quality drive the major and minor floral choices of bumble bees
}

Laurent Somme, Maryse Vanderplanck, Denis Michez, Isabelle Lombaerde, Romain Moerman, Bernard Wathelet, Ruddy Wattiez, Georges Lognay, Anne-Laure Jacquemart

\section{To cite this version:}

Laurent Somme, Maryse Vanderplanck, Denis Michez, Isabelle Lombaerde, Romain Moerman, et al.. Pollen and nectar quality drive the major and minor floral choices of bumble bees. Apidologie, 2015, 46 (1), pp.92-106. 10.1007/s13592-014-0307-0 . hal-01284427

\section{HAL Id: hal-01284427 https://hal.science/hal-01284427}

Submitted on 7 Mar 2016

HAL is a multi-disciplinary open access archive for the deposit and dissemination of scientific research documents, whether they are published or not. The documents may come from teaching and research institutions in France or abroad, or from public or private research centers.
L'archive ouverte pluridisciplinaire HAL, est destinée au dépôt et à la diffusion de documents scientifiques de niveau recherche, publiés ou non, émanant des établissements d'enseignement et de recherche français ou étrangers, des laboratoires publics ou privés. 


\title{
Pollen and nectar quality drive the major and minor floral choices of bumble bees
}

\author{
Laurent SOMME ${ }^{1}$, Maryse VANDERPLANCK ${ }^{2}$, Denis MicheZ ${ }^{2}$, Isabelle LOMBAERDE ${ }^{1}$, \\ Romain Moerman ${ }^{2,6}$, Bernard Wathelet ${ }^{3}$, Ruddy WatTIEZ ${ }^{4}$, Georges LognaY ${ }^{5}$, \\ Anne-Laure JACQUEMART ${ }^{1}$

\footnotetext{
${ }^{1}$ Earth and Life Institute - Research group Genetics, Reproduction, Populations, Université catholique de Louvain (UCL), Croix-du-Sud 2, Box L7.05.14, 1348, Louvain-la-Neuve, Belgium ${ }^{2}$ Laboratory of Zoology, University of Mons - UMONS, Place du Parc 20, 7000, Mons, Belgium

${ }^{3}$ Industrial Biological Chemistry unit, Gembloux Agro-Bio Tech, University of Liège, Passage des Déportés 2, 5030, Gembloux, Belgium

${ }^{4}$ Department of Proteomic and Protein Biochemistry, University of Mons - UMONS, Place du parc 20, 7000, Mons, Belgium Belgium

${ }^{6}$ Evolutionary Biology \& Ecology, Université Libre de Bruxelles (ULB), Avenue F.D. Roosevelt 50, 1050, Brussels, Belgium
} \\ ${ }^{5}$ Unit of Analytical Chemistry, Gembloux Agro-Bio Tech, University of Liège, Passage des Déportés 2, 5030, Gembloux,
}

Received 22 January 2014 - Revised 16 June 2014 - Accepted 7 July 2014

\begin{abstract}
To investigate whether floral resource quality impacts on bumble bee floral choices, we determined the pollen foraging constancy and floral choices of four bumble bee species commonly occurring in peaty, wet meadows in South Belgium. We subsequently analyzed the chemical contents of pollen and nectar, as well as the nectar production of the major host plant species. Individuals of B. lapidarius and B. pascuorum collected high-quality pollen (i.e., having high essential amino acid and phytosterol content) on Comarum palustre and Trifolium pratense, whereas individuals of $B$. terrestris s.l. and B. hypnorum enlarged their diet breadth to less valuable pollen resources (Cirsium palustre and Valeriana repens). Since Persicaria bistorta and Comarum palustre offer abundant and concentrated nectar, these plant species might represent major nectar sources for bumble bee species in peaty, wet meadows. The present study demonstrated the role of pollen composition on differences in foraging strategies among bumble bee species.
\end{abstract}

\section{amino acids / floral rewards / nectar sugars / phytosterols / polylectism}

\section{INTRODUCTION}

Most flowering plant species depend on animals to ensure effective pollination (Ollerton et al.

Electronic supplementary material The online version of this article (doi:10.1007/s13592-014-0307-0) contains supplementary material, which is available to authorized users.

Corresponding author: L. Somme, laurent.somme@uclouvain.be Manuscript editor: James Nieh
2011). They display various features to attract pollinators such as flower color, shape, and odor (Raguso 2004). Flowers also provide nectar and pollen as rewards (Southwick et al. 1981; Waser 1986). For bees, they represent unique food sources for both adults and larvae (Michener 2007). Bee-pollinated plant species usually show nectar and pollen of high quality (i.e., nutritional value) and/or in large amounts (but see Ayasse et al. 2011; Juillet and Scopece 2010), though these represent energy costs (Proctor et al. 1996; Schlindwein et al. 2005). 
It is commonly accepted that nectar represents the major energy source for many flower visitors, although bees also mix it with pollen for larvae provision (Cnaani et al. 2006; Waser and Ollerton 2006). Nectar consists largely of sugars (mainly sucrose, glucose, and fructose) and water, but it also contains various minor constituents such as amino acids or lipids that may, directly or indirectly, have nutritional significance (Corbet 2003; Gonzalez-Teuber and Heil 2009). The energy value of nectar depends on its volume and total sugar concentration (Cnaani et al. 2006; Nicolson 2011).

Pollen is one of the prime nutrient resources used for bee larva development (Génissel et al. 2002; Kitaoka and Nieh 2009; Michener 2007). It consists mostly of lipids (including phytosterols), proteins, amino acids, sugars, and vitamins (Day et al. 1990; Roulston et al. 2000; Vanderplanck et al. 2014a, 2011). Bees need to assimilate amino acids from pollen, especially some essential amino acids (e.g., leucine, valine, and isoleucine; De Groot 1953). Although they are considered to be non-essential amino acids, proline, aspartic, and glutamic acids are important as energy and nitrogen sources (Chapman 2012). Phytosterols are further requisite nutrients since they are precursors of molting hormones, and bees are not able to synthesize them de novo (Behmer and Nes 2003; Cohen 2004). All these essential nutrients are highly variable among plant species (Rasmont et al. 2005; Roulston et al. 2000; Vanderplanck et al. 2014a).

The abundance and quality of rewards greatly influence the foraging behavior of plant visitors, especially for generalist bees like bumble bees. Bumble bees are a popular and well-examined group of pollinators (Goulson 2009). They have been reported to discriminate between small differences in nectar concentration and to prefer sugar concentrations higher than $40 \%$ dry weight (Cnaani et al. 2006). Studies have reported bumble bees to forage preferentially on pollen with high protein content (Hanley et al. 2008; Leonhardt and Blüthgen 2012; Robertson et al. 1999), although amino acid composition could better determine the pollen required by bees (Cook et al. 2003; Nicolson 2011). Moreover, their floral choices can quickly change. Bumble bees have been reported to concentrate on patches of abundantly flowering, resource-rich plant species, though they might switch to more rewarding, alternative plant species when they become available (Fontaine et al. 2008; Goulson and Darvill 2004; Liao et al. 2011). Although bumble bees can visit various plant species for pollen, for nectar, or for both during one foraging trip, they can also focus only on one flowering species during a foraging bout (Gruter and Ratnieks 2011; Ishii 2005; Stout and Goulson 2002), ensuring the higher deposition of conspecific pollen grains on stigmas, as well as plant reproductive success. Bumble bee constancy on attractive plants might then profit both partners.

Studies usually focus on the bumble bee's host plant use and foraging constancy (Carvell et al. 2006; Connop et al. 2010; Kleijn and Raemakers 2008), or on the pollen nutritive value of several plant species (Hagbery and Nieh 2012; Leonhardt and Blüthgen 2012; Tasei and Aupinel 2008; Vanderplanck et al. 2014b). However, the bee's host plant choices coupled with the nectar and pollen quality of host plants have been rarely addressed (Hanley et al. 2008; Leonhardt and Blüthgen 2012). Moreover, to our knowledge, no studies have presented comprehensive comparative chemical analyses (i.e., polypeptides, amino acids, and sterols) of floral rewards of the main plant resources. For decades, a decline in bumble bee populations has been documented; this decline is triggered by the fragmentation and quality shift of the bees' habitats, which might induce a floral resources shift (Carvalheiro et al. 2013; Goulson et al. 2008). In this context, assessing the bumble bee's floral visitation network and its nutritional value is essential to proposing conservation strategies.

We focused our study on the floral visitation network of the main pollinators of Comarum palustre (Rosaceae). This plant species occurs in wet meadows and peat bogs, which represent refuges for many rare plant species, since these biotopes occur nowadays as fragments in a mosaic of woody and semi-natural biotopes (Frankard et al. 1998; Gibbs 2000; Verté 2007). Among these threatened species, Comarum palustre is particularly dependent on bumble bees to ensure its reproductive success (Somme et al. 2014). We 
assessed the pollen foraging constancy and floral choices of four bumble bee species (Bombus hypnorum, B. lapidarius, B. pascuorum, and B. terrestris s.l.) that commonly occur in peaty, wet meadows in South Belgium (Mayer et al. 2012; Somme et al. 2014). We collected the pollen loads of bumble bees for accurate and quantitative estimates of their pollen foraging constancy and floral choices. We subsequently analyzed the chemical content of nectar and pollen, as well as the nectar production of the major host plants of the floral visitation network. We specifically aimed to answer the following questions: (1) Are bumble bee species differently constant in their pollen collection habits, and (2) do the qualities of nectar and pollen explain the bees' different choices?

\section{METHODS}

\subsection{Bumble bee pollen loads}

\subsubsection{Pollen loads for constancy estimates}

We sampled the pollen loads of bumble bees in three sites in South Belgium in 2011: Bihain ( $50^{\circ} 14^{\prime} 25.89^{\prime \prime} \mathrm{N}$, $\left.5^{\circ} 48^{\prime} 22.60^{\prime \prime E}\right)$, Chantemelle $\left(49^{\circ} 39^{\prime} 33.51^{\prime \prime} \mathrm{N}\right.$, $\left.5^{\circ} 39^{\prime} 54.89^{\prime \prime} \mathrm{E}\right)$, and Joubiéval $\left(50^{\circ} 15^{\prime} 37.69^{\prime \prime} \mathrm{N}\right.$, $\left.5^{\circ} 50^{\prime} 20.78^{\prime \prime E}\right)$. The main flowering plant species in all three populations were Cirsium palustre, Comarum palustre, Lychnis flos-cuculi, Persicaria bistorta, and Valeriana repens. These plant species are visited by bumble bees as sources of pollen and/or nectar (see e.g., Comba et al. 1999; Goulson and Darvill 2004; Guillén et al. 2005). Pollen loads were collected from 58 bumble bee workers visiting Comarum palustre (Bombus hypnorum, $n=11$; B. lapidarius, $n=12$; B. pascuorum, $n=5$; and B. terrestris s.l., $n=30$ ). Due to their high morphological similarity, individuals of B. terrestris, B. lucorum, B. cryptarum, and B. magnus were pooled into one operational taxonomic unit (OTU), B. terrestris s.l.(Carolan et al. 2012; PrysJones and Corbet 2011). After the worker bees were immobilized in a marking cage with a soft plunger, the two pollen loads were gently removed using a toothpick. Pairs of pollen loads were acetolyzed (Erdtman 1960) and pollen grains were identified under light microscopy (Wild-Heerbrugg M3B) at a magnification of $450 \mathrm{x}$. Pollen identification was based on a reference collection from the Université catholique de Louvain, an identification key (Beug 2004), and a comprehensive list of blooming plants in the study sites. The amount of pollen was determined for each plant species and pairs of pollen loads. At least 400 pollen grains for each of the 58 pairs of pollen loads were identified and counted.

\subsubsection{Pollen loads for chemical analyses}

Small flower size and/or low pollen volume prevented us from directly sampling pollen from inflorescences. We sampled the pure pollen loads of four dominant plant species (Cirsium palustre, Comarum palustre, Trifolium pratense, and Valeriana repens) by placing a colony of B. terrestris (Biobest, Westerlo, Belgium) in a flight tent with bunches of flowers of the target species in June and July 2012. We sampled Trifolium pratense, as this plant was present at the edge of the study sites and is highly attractive to bumble bees (Carvell 2002; Goulson and Darvill 2004). We were not able to collect a sufficient amount of pure pollen loads from Lychnis flos-cuculi and Persicaria bistorta to perform further analysis on pollen composition.

\subsection{Chemical analyses of pollen loads}

\subsubsection{Polypeptide analysis}

The polypeptide content was quantified from $5 \mathrm{mg}$ dry pollen of each species in triplicate, following the method described in Vanderplanck et al (2014a). The pollen was first ground by bead beating under nitrogen. The polypeptide purification protocol combines washes and a phenol/SDS extraction. The procedure can be summarized as follows: (i) three successive wash steps with, respectively, TCA/acetone, methanolic ammonium acetate, and acetone to remove contaminants; (ii) the elimination of acetone to achieve pellet dryness; (iii) polypeptide extraction with a phenol/ SDS mixture; (iv) polypeptide precipitation from the phenol phase with methanolic ammonium acetate; (v) washes (methanol and acetone) and formation of airdried polypeptide pellets; and (vi) resuspension of the polypeptide pellets in a $4 \mathrm{M}$ guanidine. $\mathrm{HCl}$ buffer. The quantification of total polypeptide content was performed using the standard curve of the BCA Protein Assay Kit (Pierce, Thermo Scientific) at the University of Mons (Mons, Belgium). 


\subsubsection{Amino acid analysis}

The amino acid content was quantified from 2$3 \mathrm{mg}$ dry pollen of each species in triplicate. To each sample we added $1 \mathrm{ml}$ of hydrolysis solution (6 $\mathrm{N} \mathrm{HCl}, 0.1 \%$ phenol, and $500 \mu \mathrm{M}$ norleucine). Norleucine constituted the internal standard allowing further amino acid quantification after the determination of each response factor. Only tryptophan was omitted because its isolation requires a separate alkaline hydrolysis from an additional amount of sample. Moreover, tryptophan is hardly ever a limiting essential amino acid (Standifer et al. 1980). Tubes were placed for 1 min under nitrogen to avoid methionine degradation, and then incubated for $24 \mathrm{~h}$ at $110{ }^{\circ} \mathrm{C}$. The hydrolysate was evaporated until dryness was reached under a vacuum in a boiling bath at $100{ }^{\circ} \mathrm{C}$. Afterwards, $1 \mathrm{~mL}$ of buffer $\mathrm{pH} 2.2$ was added into each tube. The sample solution was mixed and poured into a high-performance liquid chromatography (HPLC) vial after filtration $(0.2 \mu \mathrm{m})$. Total amino acids were measured separately with an ion exchange chromatograph and post-column ninhydrin derivatization (Biochrom 20 plus amino acid analyser) at the University of Liège (Gembloux, Belgium).

Essential amino acids for bumble bees were considered to be those identified as essential for honey bees (i.e., arginine, isoleucine, leucine, lysine, methionine, phenylalanine, theronine, valine, and histidine; De Groot 1953).

\subsubsection{Phytosterol analysis}

Phytosterol content was analyzed from $15 \mathrm{mg}$ dry pollen of each species, in duplicate or triplicate, according to the method described in Vanderplanck et al (2011). The procedure can be summarized as follows: (i) saponification of the samples with methanolic potassium hydroxide; (ii) extraction of the unsaponifiable (USM) part with diethylether and water-washings of the organic phase; (iii) evaporation of the solvent; (iv) USM fractionation into its components using thin-layer chromatography (TLC); (v) derivatization of the sterols (scraped from the silicagel) into trimethylsilyl ethers (TMS); and (vi) separation of the TMS by gas liquid chromatography (GLC). The total phytosterol content was determined by considering all the peaks of sterols (the upper limit of detection, LOD) eluted between cholesterol and betulin. Individual sterols, which were quantified on the basis of peak areas from analyses of a $0.05-\mathrm{mg} / \mathrm{mL}$ cholesterol/betulin solution, were expressed as percentages of the total sterol content. Identifications were achieved by comparing the relative retention times $(\beta$-sitosterol $-\mathrm{TMS}=1.00)$ with those of a sunflower oil reference, prepared according to the work of Lognay et al (1992). These identifications were checked by GC/MS (gas chromatograph/mass spectrometer) analyses at the University of Liège (Gembloux, Belgium; Vanderplanck et al. 2011).

\subsection{Nectar sampling and chemical analyses}

We sampled nectar at the peak of flowering of each plant species between late May and early July 2012. To have easier access to the nectar and to avoid pollen contamination, anthers and stigmas were removed from flowers of Cirsium palustre, Lychnis flos-cuculi, Persicaria bistorta, Trifolium pratense, and Valeriana repens. For each plant species, nectar was collected from freshly opened flowers with glass capillary tubes of $0.5 \mu \mathrm{L}, 1 \mu \mathrm{L}$ or $5 \mu \mathrm{L}$, depending on the nectar quantity (Hirschmann ${ }^{\circledR}$ Laborgerate, Eberstadt, Germany). The nectar volume was estimated by measuring the length of the nectar column in the capillary tube.

Nectar samples were stored in capillary tubes at $-80{ }^{\circ} \mathrm{C}$ until we performed the analyses of their sugar concentration and composition. Sugar composition was determined by gas chromatography, with a Perkin-Elmer Autosystem XL equipped with a split injector $(1 / 20)$ and helium as the carrier gas (flow of $1 \mathrm{~mL} / \mathrm{min}$ ). The injector and detector temperatures were maintained at 250 and $350{ }^{\circ} \mathrm{C}$, respectively. Sugar (i.e., sucrose, glucose and fructose) analyses for nectar composition were performed in the Centre Apicole de Recherche et d'Information (CARI asbl, Louvain-la-Neuve, Belgium).

\subsection{Statistical analyses}

\subsubsection{Floral choices and pollen chemical composition}

We performed Kruskal-Wallis tests to compare the proportion of different pollen grains and the number of plant species within pollen loads among bumble bee species. 
We further used Kruskal-Wallis tests to compare polypeptide, amino acid, essential amino acid, and phytosterol content among the four plant species.

To test differences in chemical composition among pollen, we performed a permutational multivariate analysis of variance (perMANOVA) using the Bray-Curtis dissimilarity matrix and 999 permutations ("adonis" command, R-package vegan; Oksanen et al. 2013). Prior to this perMANOVA, the multivariate homogeneity of within-group covariance matrices was verified using the "betadisper" function. When a significant difference was detected $(p<0.05)$, multiple pairwise comparisons were conducted on the data to detect precisely the differences, and $p$-values were adjusted using Bonferroni's correction to avoid increases of type error I due to multiple testing. Both similarities and dissimilarities in chemical compositions (phytosterols and essential amino acids) among the different pollen sources (i.e., Cirsium palustre, Comarum palustre, Trifolium pratense, and Valeriana repens) were visually assessed using non-metric, multidimensional scaling ordinations (nMDS) based on the Bray-Curtis dissimilarity matrix, two dimensions, and 50 runs. Statistics were conducted in $\mathrm{R}$ using functions from ecodist (Goslee and Urban 2007) and BiodiversityR (Kindt and Coe 2005). We performed an indicator compound analysis using the "indval" function from the R package LabDSV (Dufrêne and Legendre 1997; Roberts 2012) to identify the compounds that were uniquely present in each pollen type. All these multivariate analyses were conducted in $\mathrm{R}$, version 2.15.1 ( $\mathrm{R}$ Development Core Team 2012).

\subsubsection{Nectar production and composition}

For each plant species investigated for nectar composition, we estimated the sugar ratio $(R)$, which is defined as the ratio by weight of sucrose to the combined hexose sugars (i.e., fructose and glucose): $R=S /$ $(F+G)$, where $S, F$, and $G$ represent the percentages of sucrose, fructose, and glucose, respectively (Baker and Baker 1990). Four classes of nectar, depending on sugar ratio, were defined by Baker and Baker (1990): sucrosedominant $(R>1)$, sucrose-rich $(0.5>R>1)$, hexose-rich $(0.1>R>0.5)$, and hexose-dominant $(R<0.1)$. The volume of produced nectar and relative concentrations in sucrose, fructose, and glucose were compared using the Kruskal-Wallis tests.
If not indicated otherwise, data are presented as means \pm standard deviation. Analyses were computed with R 2.15.1 (R Development Core Team 2012).

\section{RESULTS}

\subsection{Bumble bee plant choices and constancy}

About $60.2 \%$ of the pollen loads were pure in floral composition (i.e., > $95 \%$ conspecific pollen grains; Table S1), and $86.1 \%$ of them contained pure pollen of Comarum palustre. Overall, $90.2 \%$ of the pollen loads contained pollen from C. palustre. Bombus terrestris s.l. presented a lower abundance of individuals carrying pure pollen loads (33.3\%) than B. hypnorum (63.6\%), B. lapidarius (75.0 \%), and B. pascuorum (80.0\%; Table S1). The major pollen resource was Comarum palustre for the four bumble bee species (Table I). The average proportion of $C$. palustre pollen per load differed significantly among bumble bee species $\left(\chi^{2}=9.04, \mathrm{df}=3, P<0.05\right.$; Table I). It was especially high for B. pascuorum and B. lapidarius (92.6$95.5 \%$ ). Minor pollen resources depended on bumble bee species. Angelica sylvestris, Galium sp., Ranunculus acris, and Valeriana repens were alternative pollen resources for B. hypnorum (24.5\% of all pollen grains are from these four plant species) and B. terrestris s.l. (26.1\%), while B. lapidarius and $B$. pascuorum did not forage on pollen of these plant species. Moreover, B. terrestris s.l. is the only group of bumble bee species that collected pollen from Cirsium palustre (5\%). The number of plant taxa in individual pollen loads (mean $=2.5 \pm 0.2$ species) ranged from one to seven species, though it did not differ significantly among bumble bee species $\left(\chi^{2}=2.05, \mathrm{df}=3, P>0.05\right.$; Table S1). Yet, B. terrestris s.l. showed the broadest diet with a total of 12 different plant species over all loads (Table S1; Table I).

\subsection{Pollen composition}

\subsubsection{Polypeptide and total amino acid contents}

The polypeptide content of pollen was not significantly different among plant species $\left(\chi^{2}=6.89\right.$, 
Table I. Percentage (mean \pm SD) of pollen grains of the different plant species present in pollen loads of Bombus hypnorum, B. lapidarius, B. pascuorum, and B. terrestris s.l.. Only plant species present in more than $2 \%$ of the pollen loads are shown. Other species are listed in Table S1

\begin{tabular}{lllll}
\hline & $\begin{array}{l}\text { B. hypnorum } \\
(n=11)\end{array}$ & $\begin{array}{l}\text { B. lapidarius } \\
(n=12)\end{array}$ & $\begin{array}{l}\text { B. pascuorum } \\
(n=5)\end{array}$ & $\begin{array}{l}\text { B. terrestris s.l. } \\
(n=31)\end{array}$ \\
\hline Angelica sylvestris & $5.9 \pm 19.5$ & - & - & $0.9 \pm 3.9$ \\
Cirsium palustre & $*$ & $*$ & $0.2 \pm 0.4$ & $4.4 \pm 17.5$ \\
Comarum palustre & $74.6 \pm 41.4$ & $95.5 \pm 8.9$ & $92.6 \pm 13.3$ & $61.6 \pm 42.3$ \\
Galium sp. & $9.0 \pm 29.2$ & - & - & $3.0 \pm 17.2$ \\
Lychnis flos-cuculi & $*$ & $0.7 \pm 1.5$ & $0.2 \pm 0.3$ & $6.3 \pm 20.6$ \\
Persicaria bistorta & $1.0 \pm 2.6$ & $*$ & $0.4 \pm 0.5$ & $0.2 \pm 0.8$ \\
Ranunculus acris & $0.5 \pm 1.0$ & - & - & $11.3 \pm 29.0$ \\
Trifolium pratense & - & $2.5 \pm 6.1$ & $5.9 \pm 11.9$ & $0.3 \pm 1.1$ \\
Valeriana repens & $9.1 \pm 30.2$ & $*$ & - & $10.9 \pm 27.3$ \\
\hline
\end{tabular}

$n$ number of analyzed pollen loads containing more than 50 pollen grains per load, * species present in a proportion lower than $0.2 \%$, Gallium sp. Gallium palustre + G. uliginosus

$\mathrm{df}=3, P>0.05$; Table II) and ranged from $1.51 \%$ dry matter for Comarum palustre to $4.02 \%$ dry matter for Trifolium pratense.

Total amino acid content differed significantly among species, ranging from 12.42 to $21.59 \%$ dry matter $\left(\chi^{2}=8.46, \mathrm{df}=3, P<0.05\right.$; Table II). Comarum palustre and Trifolium pratense contained pollen with a higher content of essential amino acids ( 9.85 and $11.22 \%$ dry matter, respectively) than Valeriana repens and Cirsium palustre, which contained 6.11 and $8.26 \%$, respectively $\left(\chi^{2}=8.82, \mathrm{df}=3, P<0.05\right.$; Table II $)$. The relative proportion of essential amino acids differed significantly between plant species. For instance, Trifolium pratense contained a higher relative concentration of essential amino acids (51.99\%) compared to Comarum palustre and
Valeriana repens (46.78 and $46.65 \%$, respectively; $\chi^{2}=9.87, \mathrm{df}=3, P<0.05$; Table II).

PerMANOVA detected a significant difference in the composition of essential amino acids (free and protein-bound, pooled) among the pollen $\left(F_{3,10}=8.62, P<0.01\right)$. Pairwise comparisons indicated a significant difference between Cirsium palustre and Comarum palustre $\left(F_{1,5}=15.33\right.$, $P<0.001$ ), but did not clearly arrange the different species into groups. As shown by nMDS ordination, the different species overlapped despite some slight differences (stress value $=0.019$, Figure 1). Moreover, the essential amino acid profiles were quite similar among the species, as our indicator compound analysis did not detect significant associations between any essential amino acid and any pollen type. Regardless, non-essential amino

Table II. Polypeptide and total amino acid contents of pollen from the four studied species expressed as a percentage of dry weight (mean $\pm \mathrm{SD}$ ), and essential amino acid proportion expressed as a percentage of total amino acid content (mean $\pm \mathrm{SD})$.

\begin{tabular}{llll}
\hline & $\begin{array}{l}\text { Polypeptide } \\
\text { content }(\%)\end{array}$ & $\begin{array}{l}\text { Total amino acid } \\
\text { content }(\%)\end{array}$ & $\begin{array}{l}\text { Essential amino } \\
\text { acids (\%) }\end{array}$ \\
\hline Cirsium palustre $(n=3)$ & $1.66 \pm 0.32$ & $12.42 \pm 2.85$ & $49.17 \pm 0.45$ \\
Comarum palustre $(n=3)$ & $1.51 \pm 0.31$ & $21.06 \pm 1.52$ & $46.78 \pm 0.47$ \\
Trifolium pratense $(n=3)$ & $4.02 \pm 1.19$ & $21.59 \pm 2.76$ & $51.99 \pm 0.11$ \\
Valeriana repens $(n=3)$ & $1.78 \pm 0.37$ & $17.71 \pm 3.11$ & $46.65 \pm 0.24$ \\
\hline
\end{tabular}


Stress value $=0.019$

$\mathrm{R}^{2}=0.999$

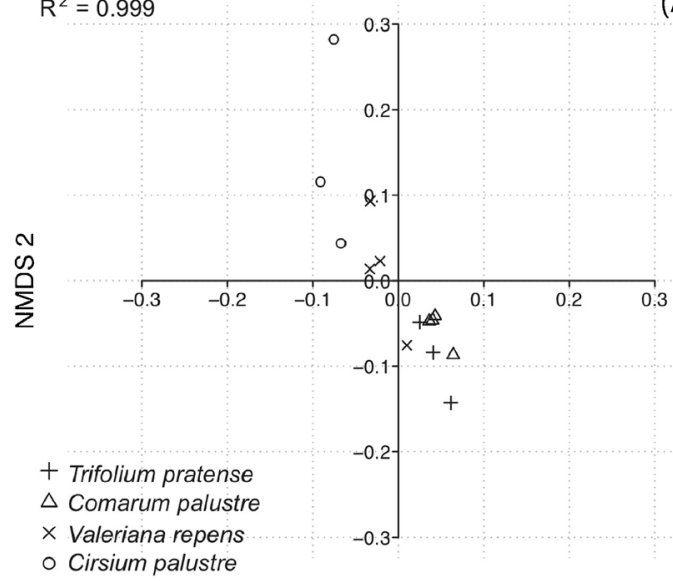

(A)

(B)

Figure 1. nMDS ordination plot based on Bray-Curtis distances calculated on abundances ( $\mathrm{mg} / \mathrm{g})$ of essential amino acids in pollen of the four plant species: (A) replicates within species and (B) essential amino acid vectors with a arginine, $\mathrm{b}$ histidine, $\mathrm{c}$ isoleucine, $\mathrm{d}$ leucine, e lysine, $\mathrm{f}$ methionine, $\mathrm{g}$ phenylalanine, $\mathrm{h}$ threonine, and $\mathrm{i}$ valine. Stress value $=0.019$ and $R^{2}=0.999$.

acids from the pollen of Cirsium palustre contained higher relative abundances of glutamic acid plus glutamine and aspartic acid plus asparagine, and less proline than the three other plant species $\left(\chi^{2}=10.49-10.83\right.$ respectively, $\mathrm{d} f=3$, $P<0.05$; Figure 2).

\subsubsection{Phytosterol content}

Total phytosterol contents ranged from 4.84 to $10.50 \%$ dry matter for Valeriana repens and Trifolium pratense, respectively (Table III). The major phytosterols were the 24methylenecholesterol/campesterol fraction (14.22-61.21\%), $\beta$-sitosterol (5.21-29.88\%), and $\delta 5$-avenasterol (10.62-23.20\%; Table III). The relative concentrations of cholesterol, desmosterol (except for Comarum palustre), stigmasterol, cholestenone, 87 -avenasterol, and 87 stigmasterol (except for Cirsium palustre) were lower than $10 \%$ (Table III).

PerMANOVA detected a significant difference in sterol composition among the four pollens $\left(F_{3,5}=53.04, P<0.001\right)$. Pairwise comparisons and nMDS ordination arranged the different species into three distinctive groups (stress value $=0.084$; Figure 3): (i) one including Trifolium pratense and Valeriana repens
$\left(F_{1,3}=81.07, P=0.066\right)$, (ii) an intermediate group including Comarum palustre, which did not significantly differ from Trifolium pratense $\left(F_{1,3}=24.54, P>0.05\right)$ and Cirsium palustre $\left(F_{1,2}=35.97, P>0.05\right)$, and (iii) one with Cirsium palustre. Indicator compound analysis did not reveal significant sterol/ pollen association. However, the pollen of Cirsium palustre displayed a high amount of 87-stigmasterol (24.25-30.05\%).

\subsection{Nectar volume and composition}

Flowers of Comarum palustre produced significantly higher amounts of nectar than flowers of the other plant species $\left(\chi^{2}=238.1\right.$, $\mathrm{df}=5, P<0.001$; Table IV). Nectar production was the highest at the flower head level for Persicaria bistorta $(14.9 \mu \mathrm{L})$ and Trifolium pratense $(20.9 \mu \mathrm{L})$. Flowers of Comarum palustre presented hexose-dominant nectar $(R=0.01)$, whereas other plant species were sucrose-rich (Persicaria bistorta; $R=0.82$ ) or sucrose-dominant (Lychnis flos-cuculi, Valeriana repens, Cirsium palustre, Trifolium pratense, $R=1.23-11.28$; Table IV). Overall, nectars differed significantly in their fructose, glucose, and sucrose concentrations $\left(\chi^{2}=14.2-\right.$ 


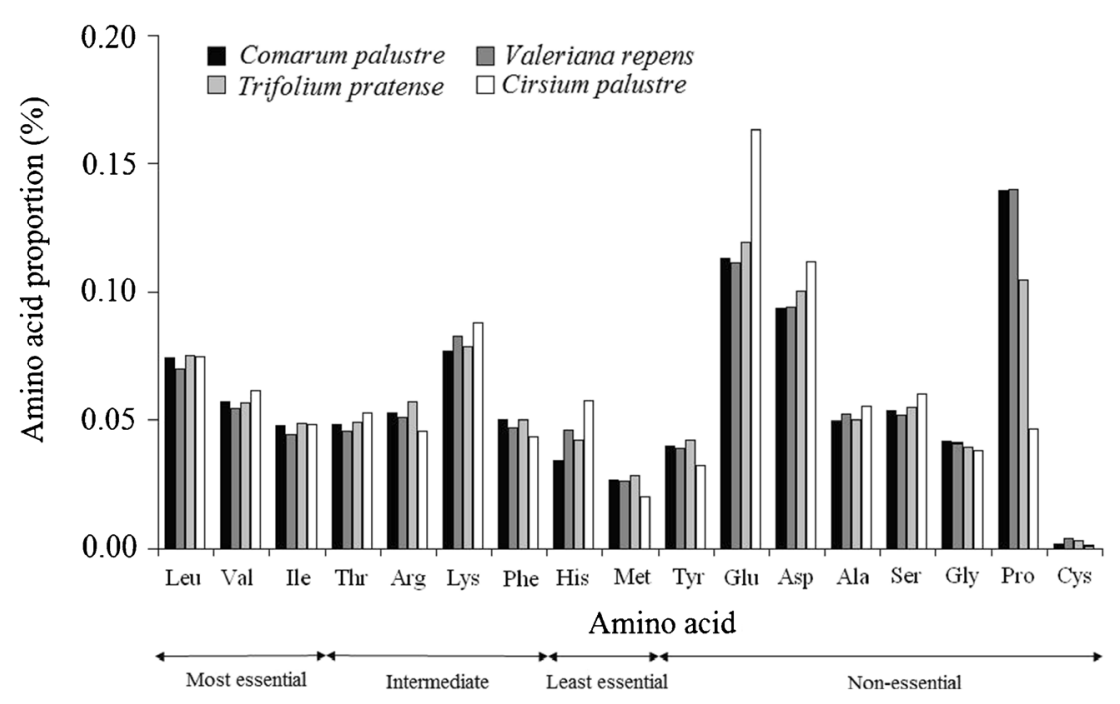

Figure 2. Total amino acid profiles of the four different pollen species (Comarum palustre, Trifolium pratense, Valeriana repens, and Cirsium palustre). The amino acids are ordered into four groups according to their relative required amounts in the diet of the honey bee: most, intermediate, least, and non-essential (De Groot 1953). (Leu= leucine, $\mathrm{Val}=$ valine, Ile=isoleucine, $\mathrm{Thr}=$ theronine, $\mathrm{Arg}=$ arginine, $\mathrm{Lys}=$ lysine, $\mathrm{Phe}=$ phenylalanine, His $=$ histidine, Met $=$ methionine, $\mathrm{Glx}=$ glutamic acid + glutamine, $\mathrm{Asx}=$ aspartic acid + asparagine, $\mathrm{Ala}=$ alanine, Ser $=$ serine, Gly $=$ glycin, Pro=proline, Cys $=$ cysteine) .

15.6, $\mathrm{df}=5, P<0.05$; Figure 4). Comarum palustre presented the highest concentration in glucose and fructose $(0.26$ and $0.28 \mathrm{mg} / \mathrm{g}$, respectively), whereas Lychnis flos-cuculi presented the highest concentration in sucrose $(0.05 \mathrm{mg} / \mathrm{g})$.

Table III. Sterolic compounds for the four studied species (range)

\begin{tabular}{|c|c|c|c|c|}
\hline Sterols & $\begin{array}{l}\text { Comarum } \\
\text { palustre } \\
(n=2)\end{array}$ & $\begin{array}{l}\text { Valeriana } \\
\text { repens } \\
(n=2)\end{array}$ & $\begin{array}{l}\text { Trifolium } \\
\text { pratense } \\
(n=3)\end{array}$ & $\begin{array}{l}\text { Cirsium } \\
\text { palustre } \\
(n=2)\end{array}$ \\
\hline Cholesterol & $2.19-2.71$ & $5.68-5.81$ & $1.24-3.30$ & $6.22-6.27$ \\
\hline Desmosterol & $10.10-11.97$ & $<$ LOD & $<$ LOD & $7.43-9.09$ \\
\hline 24-Methylenecholesterol/ campesterol $^{\mathrm{a}}$ & $36.60-37.06$ & $34.19-37.26$ & $53.55-61.21$ & $14.22-17.19$ \\
\hline Stigmasterol & $1.87-2.15$ & $4.20-4.99$ & $1.67-3.11$ & $2.33-2.46$ \\
\hline$\beta$-sitosterol & $17.94-18.43$ & $29.25-29.88$ & $5.21-10.35$ & $17.43-17.81$ \\
\hline$\delta 5$-avenasterol & $19.22-19.75$ & $10.62-12.83$ & 20.99-23.20 & $13.11-15.12$ \\
\hline Cholestenone & $1.61-3.54$ & $2.84-3.24$ & $2.35-3.18$ & $1.81-4.08$ \\
\hline$\delta 7$-stigmasterol & $2.46-6.91$ & $5.30-5.73$ & $2.32-3.55$ & $24.25-30.05$ \\
\hline$\delta 7$-avenasterol & $2.25-3.24$ & $3.20-3.37$ & $1.04-1.70$ & $4.99-6.13$ \\
\hline TOTAL (\%) & $7.59-9.01$ & $4.84-5.21$ & $9.98-10.50$ & $5.26-5.39$ \\
\hline
\end{tabular}

Concentrations are expressed as a percentage of the total sterolic compounds. Species are ordered according to overall decreasing abundance among corbicular pollen loads. The three major sterols in the investigated samples are in bold. $<$ LOD, under limit of detection ${ }^{\text {a }}$ Under the analytical conditions applied, campesterol and 24-methylenecholesterol were nearly impossible to separate; the results were therefore pooled 

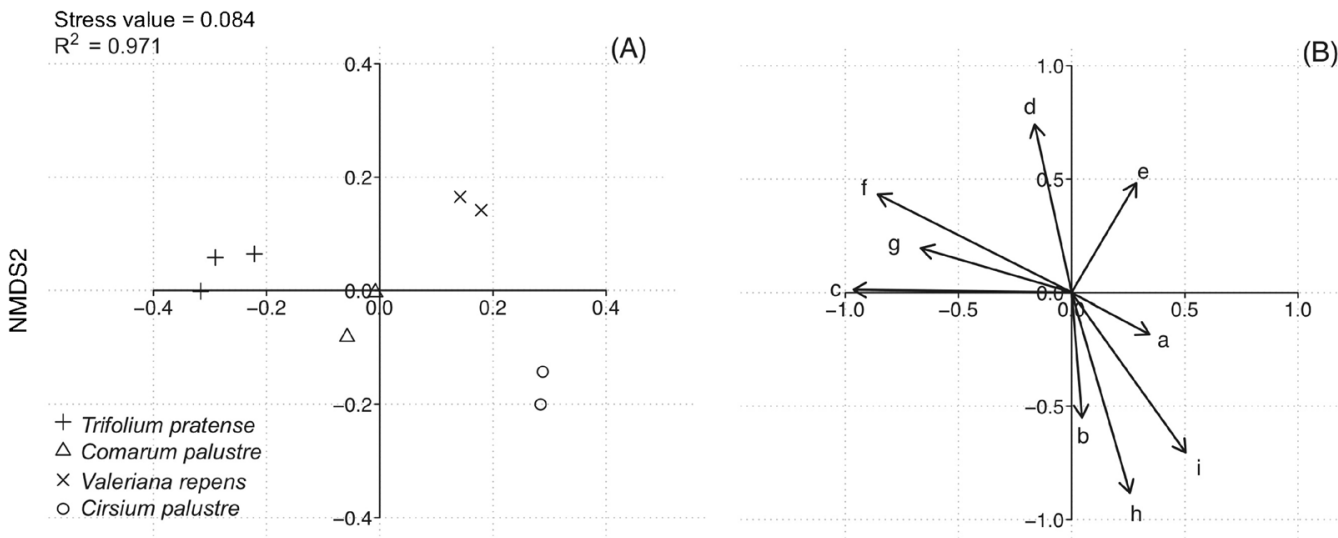

NMDS1

Figure 3. nMDS ordination plot based on Bray-Curtis distances, calculated on the abundances $(\mathrm{mg} / \mathrm{g})$ of phytosterolic compounds in the pollen of the four plant species: (A) replicates within species and (B) sterolic vectors with a cholesterol, b desmosterol, c 24-methylenecholesterol/campesterol, d stigmasterol, e $\beta$-sitosterol, $\mathrm{f}$ $\delta 5$-avenasterol, g cholestenone, h $\delta 7$-stigmasterol, and i $\delta 7$-avenasterol. Stress value $=0.0184$ and $R^{2}=0.971$

\section{DISCUSSION}

\subsection{Bumble bee floral choices}

Analyzing the pollen loads of bumble bee individuals allowed us to determine their pollen resources and their relative constancy. Bumble bee individuals sampled on flowers of Comarum palustre were highly constant during pollen collection. However, as previously shown in other studies (Carvell et al. 2006; Goulson and Darvill 2004), differences were observed among bumble bee species in their degree of constancy. Bombus lapidarius and B. pascuorum showed higher constancy than B. terrestris s.l.. In particular, pollen loads from $B$. lapidarius and $B$. pascuorum contained almost $100 \%$ pollen from Comarum palustre, Lychnis flos-cuculi, or Trifolium pratense, whereas pollen loads of individuals of $B$. terrestris s.l. contained up to four major pollen species. Pollen loads of $B$. hypnorum were mainly composed of pollen from Comarum palustre, Persicaria bistorta, or Ranunculus acris. Overall, B. terrestris s.l. showed a wider diet breadth (12) than did the three other bumble bee species (6-8). This result is not surprising since $B$. terrestris is

Table IV. Nectar volume produced per flower (mean $\pm \mathrm{SD}$ ), number of flowers per inflorescence head (mean $\pm \mathrm{SD}$ ), nectar volume per inflorescence (mean $\pm \mathrm{SD}$ ), and nectar sugar ratio $(R=S /(F+G))$ of the six studied plant species: Cirsium palustre, Comarum palustre, Lychnis flos-cuculi, Persicaria bistorta, Trifolium pratense, and Valeriana repens

\begin{tabular}{lllll}
\hline & $\begin{array}{l}\text { Nectar volume } \\
\text { per flower }(\mu \mathrm{l})\end{array}$ & $\begin{array}{l}\text { Number of flowers } \\
\text { per inflorescence }\end{array}$ & $\begin{array}{l}\text { Nectar volume per } \\
\text { inflorescence }(\mu \mathrm{l})\end{array}$ & $R$ \\
\hline Cirsium palustre $(n=25)$ & $0.04 \pm 0.07$ & $47.7 \pm 7.8$ & $1.92 \pm 0.55$ & 7.69 \\
Comarum palustre $(n=15)$ & $1.29 \pm 1.01$ & $6.6 \pm 2.7$ & $9.03 \pm 2.73$ & 0.01 \\
Lychnis flos-cuculi $(n=20)$ & $0.50 \pm 0.16$ & $11.6 \pm 6.7$ & $6.00 \pm 1.07$ & 1.23 \\
Persicaria bistorta $(n=25)$ & $0.09 \pm 0.09$ & $164.4 \pm 64.7$ & $14.85 \pm 5.82$ & 0.82 \\
Trifolium pratense $(n=20)$ & $0.19 \pm 0.18$ & $110.2 \pm 36.7$ & $20.90 \pm 6.61$ & 11.28 \\
Valeriana repens $(n=25)$ & $0.02 \pm 0.02$ & $232.8 \pm 51.4$ & $4.66 \pm 1.03$ & 1.79 \\
\hline
\end{tabular}




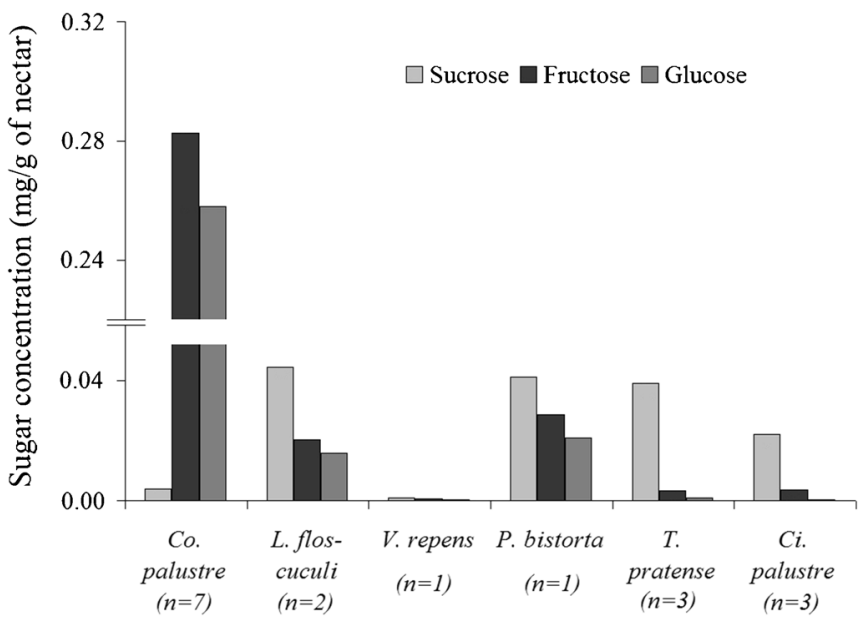

Figure 4. Mean sugar concentration in the nectar of the six species investigated for nectar composition is shown. Species are ordered according to decreasing abundance among corbicular pollen loads

considered to be the most polylectic of the bumble bee species (Goulson 2009). Yet, this result might also reflect specific foraging preferences of the four bumble bee species pooled in the OTU B. terrestris s.l. (see e.g., Waters et al. 2011). Our results on the diet breadth of $B$. lapidarius in peaty, wet meadows further support the results in agricultural landscapes, as they showed high constancy when foraging for pollen (Carvell et al. 2006; Connop et al. 2010; Leonhardt and Blüthgen 2012). However, studies showed that $B$. lapidarius can also present diet breadth as large as other co-occurring bumble bee species, or even larger (Goulson and Darvill 2004; Kleijn and Raemakers 2008). The same kind of opposite results has been shown for B. pascuorum, as two studies showed that this species presented a broader diet than B. terrestris s.l. (Carvell et al. 2006; Leonhardt and Blüthgen 2012). These conflicting results about the diet breadth of $B$. lapidarius and B. pascuorum suggested that the relative diet breadth of these species might be more related to local and temporal conditions than to fixed, specific preferences (Roulston and Goodell 2011).

The majority of plant species identified in pollen loads were present within the three study sites. However, some of the plant species (e.g., Ranunculus acris and Trifolium pratense) occurred at the margins of the wet meadows or in hay meadows in the surrounding area. Their relative abundance in pollen loads $(2.3-26.0 \%$ and $0.1-27.0 \%$, respectively) might reflect interactions between peaty, wet meadows and these margins and hay meadows. The latter usually represents potential nesting sites for the four bumble bee species sampled (Benton 2006). Further investigations on bumble bee species' movements between the peaty, wet meadows and the surrounding areas might provide further information about the interactions between the different biotopes.

\subsection{Quality of pollen rewards}

The investigated pollens differed in their total amino acid content, though they were similar in their relative abundance and full spectrum of essential amino acids. The latter are consistent with previous studies suggesting that amino acid composition is conserved among plant species (Roulston and Cane 2000; Weiner et al. 2010). High total amino acid content and related nitrogen content have been reported to differ widely among plant species (Roulston and Cane 2000) and to be positively correlated with larva weight and development, particularly with more than $20 \%$ total protein content (Génissel et al. 2002; Tasei and Aupinel 2008; Vanderplanck et al. 2014b). Therefore, the pollen of Comarum palustre and 
Trifolium pratense might be considered to be of high chemical value, as they showed total amino acid content higher than $20 \%$, whereas the pollen of Cirsium palustre would be low-quality pollen. Our results further indicated that the relative abundance of non-essential amino acids in pollen widely varied between the investigated plant species. In particular, the pollen of Comarum palustre, Trifolium pratense, and Valeriana repens showed a higher relative abundance of proline than Cirsium palustre. This non-essential amino acid has been reported in high proportions in pollen collected by honey bees and bumble bees (Leonhardt and Blüthgen 2012), which is not surprising, as this component is involved in bee flight (Carter et al. 2006). On the contrary, Cirsium palustre showed the highest relative abundance of aspartic acid plus asparagine and glutamic acid plus glutamine, both involved in nitrogen assimilation by bees (Roulston and Cane 2000) and found in high concentrations in the pollen collected by bumble bee species (Leonhardt and Blüthgen 2012). These results further support the dependence of bumble bee species on multiple pollen resources to meet their food requirements.

The pollen of Comarum palustre and Trifolium pratense contained higher proportions of phytosterols than Cirsium palustre and Valeriana repens. However, the relative abundance of phytosterols was similar among the four plant species, with 24 methylenecholestrol /campesterol, $\beta$-sitosterol, and $\delta 5$-avenasterol as the main phytosterols. The 24-methylenecholestrol has been reported to be among the most important phytosterol for bees (Human et al. 2007; Svoboda et al. 1980). $\beta$-sitosterol and $\delta 5$-avenasterol have been reported to have a phagostimulant effect on bumble bee species (Rasmont et al. 2005). Cirsium palustre contained a high relative proportion of 87-stigmasterol, which is a common sterol to several Asteraceae (Janson et al. 2009). This phytosterol might represent a chemical protection of pollen, as it has been reported to be detrimental to herbivorous insects lacking the enzymes (specifically isomerases) necessary to completely convert $\delta 7$-sterols to $\delta 5$-sterols (Janson et al. 2009; Sedivy et al. 2011).
In this study, the comprehensive, comparative chemical analysis of pollen allowed us to highlight that Comarum palustre and Trifolium pratense offered pollen of high chemical quality to bumble bee species due to their high amino acid content (including essential amino acids) and phytosterol composition. Cirsium palustre and Valeriana repens would then be considered as less valuable pollen resources for bumble bee species due to their lower amino acid and phytosterol content, and for their high relative proportion of 87 stigmasterol (Cirsium palustre).

\subsection{Quality of nectar rewards}

Nectar volume was relatively abundant at the flower level for Comarum palustre and at the flower head level for Persicaria bistorta and Trifolium pratense. The sugar ratio differed between the investigated plant species, as Comarum palustre offered hexose-dominant nectar, Persicaria bistorta offered sucrose-rich nectar, and the four other species offered sucrose-dominant nectar. Our results, except for those of Persicaria bistorta, for which the nectar was not yet analyzed, are supported by a previous study by Percival (1961). Flower morphology influenced sugar ratio, as higher proportions of hexoses compared to sucrose are typical of open flowers such as Comarum palustre and are related to high invertase activity (Nicolson 2011). In particular, Percival (1961) reported that plant species belonging to the Rosaceae (e.g., Comarum palustre) produce nectar of equal parts fructose and glucose. Comarum palustre offered nectar with a high fructose concentration $(0.28 \mathrm{mg} / \mathrm{g})$, whereas Lychnis flos-cuculi, Persicaria bistorta, and Trifolium pratense offered nectar with high concentrations of sucrose $(0.05$, 0.04 , and $0.04 \mathrm{mg} / \mathrm{g}$, respectively). Highly concentrated nectars, particularly containing hexoses, are related to the open flower morphology favoring water evaporation (Harder 1986).

Flowers of Comarum palustre therefore offered abundant nectar with a high sugar 
concentration. Other rewarding plant species in the peaty, wet meadows were Lychnis floscuculi and Persicaria bistorta.

\subsection{Floral choices and reward quality}

Interestingly, plant species offering pollen of high qualitative value (i.e., high essential amino acid and phytosterol content) were dominant in the diet of the four sampled bumble bee species. These results confirm the results of previous studies showing that bumble bees are able to evaluate the chemical quality of their resources (Kitaoka and Nieh 2009) and to forage on pollen showing high protein content (Hanley et al. 2008; Leonhardt and Blüthgen 2012). However, as C. palustre presented large stands of high flower density among study sites, the foraging preferences of bumble bee individuals might also be related to the relative abundance of host plants (Leonhardt and Blüthgen 2012; Sowig 1989).

Our results further highlighted the dependence of polylectic bumble bee species on multiple floral resources for pollen, which has been experimentally shown to positively influence larval development in raised colonies of B. terrestris (Génissel et al. 2002; Pelletier and McNeil 2003; Tasei and Aupinel 2008). However, diet breadth associated with chemical components was not similar among the four bumble bee species. While B. lapidarius and B. pascuorum focused their pollen collection on plant species showing high amino acid content (i.e., Comarum palustre and Trifolium pratense), B. hypnorum and B. terrestris s.l. expanded about $25 \%$ of their diet to plant species offering less valuable pollen. These results confirm the study of Leonhardt and Blüthgen (2012), which showed that B. pascuorum foragers collected pollen containing more protein than pollen collected by $B$. terrestris s.l. foragers. As the relative host-plant specialization of $B$. pascuorum and B. terrestris s.l. are variable (see before), differences in floral choices of the two bumble bee species might therefore be more driven by pollen chemical quality than by preference for particular plant taxa.

Our results also suggest that bumble bee competition for pollen of high chemical quality might be higher than for pollen of low quality. $B$. hypnorum and B. terrestris s.l. seemed able to increase their diet breadth on less valuable and sought-after rewards. Although a previous study of Fontaine et al. (2008) reported individuals of $B$. terrestris to enlarge their diet breadth under high competition for resources, we showed that it might be at the expense of pollen chemical quality. Moreover, $B$. terrestris s.l. was the only group of bumble bee species that collected pollen of Cirsium palustre (up to $77 \%$ of pollen loads), and this pollen might be considered as very-poorquality pollen since it contains a low concentration of amino acids and a high relative abundance of $\delta-7$ stigmasterol. Many insect species are not able to metabolize the $\delta-7$ stigmasterol, as they lack the enzyme to break the $\delta-7$ bond (Canavoso et al. 2001; Janson et al. 2009).

Finally, differences in pollen foraging strategies among bumble bee species cannot be explained by colony cycle length, tongue length, or body size, as B. terrestris s.l. and $B$. lapidarius are similar in these features (Benton 2006; Carvell et al. 2006; Goulson and Darvill 2004). We hypothesized that larvae of $B$. terrestris s.l. and B. hypnorum might easily assimilate pollen of poor chemical quality. Further investigations via comparative studies of bumble bee colony rearing on various monofloral diets might be helpful to test this hypothesis.

\section{ACKNOWLEDGMENTS}

The authors thank the Belgian Fund for Scientific Research (FNRS contract 2.4540.09) for funding this study. LS holds a FRIA fellowship (Funds for training in Industry and Agriculture Research) and MV holds an aspirant FNRS fellowship. The study was conducted in accordance with current Belgian laws. We thank the "Département de la Nature et des Forêts" (DNF, Région Wallonne, Belgium) for the derogation concerning the sampling of plant and insect individuals in nature reserves, the DNF and Natagora for granting access to their properties, and Christel Buyens and Isabelle Van de Vreken for technical assistance. 
La qualité du pollen et du nectar conditionne les choix, prioritaires ou secondaires, des fleurs par les bourdons

Acides aminés / récompense / sucre du nectar / phytostéroles / polyectisme

Die Pollen- und Nektarqualität beeinflusst die Blütenauswahl bei Hummeln

Aminosäuren / Blütenbelohnung / Nektarzucker / Phytosterole / Polylektie

\section{REFERENCES}

Ayasse, M., Stökl, J., Francke, W. (2011) Chemical ecology and pollinator-driven speciation in sexually deceptive orchids. Phytochemistry, Plant-Insect Interact. 72, 1667-1677

Baker, H.G., Baker, I. (1990) The predictive value of nectar chemistry to the recognition of pollinator types. Isr. J. Bot. 39, 157-166

Behmer, S.T., Nes, W.D. (2003) Insect sterol nutrition and physiology: a global overview. Adv. Insect Physiol. 31, 1-72

Benton, T. (2006) Bumblebees: the natural history \& identification of the species found in Britain. Collins, London

Beug, H.-J. (2004) Leitfaden der Pollenbestimmung für Mitteleuropa und angrenzende Gebiete. Friedrich Pfeil, München, Germany

Canavoso, L.E., Jouni, Z.E., Karnas, K.J., Pennington, J.E., Wells, M.A. (2001) Fat metabolism in insects. Annu. Rev. Nutr. 21, 23-46

Carolan, J.C., Murray, T.E., Fitzpatrick, Ú., Crossley, J., Schmidt, H., Cederberg, B., McNally, L., Paxton, R.J., Williams, P.H., Brown, M.J.F. (2012) Colour patterns do not diagnose species: quantitative evaluation of a DNA barcoded cryptic bumblebee complex. PLoS ONE 7, e29251

Carter, C., Shafir, S., Yehonatan, L., Palmer, R.G., Thornburg, R. (2006) A novel role for proline in plant floral nectars. Naturwissenschaften 93, 72-79

Carvalheiro, L.G., Kunin, W.E., Keil, P., Aguirre-Gutiérrez, J., Ellis, W.N., Fox, R., Groom, Q., Hennekens, S., Van Landuyt, W., Maes, D., et al. (2013) Species richness declines and biotic homogenisation have slowed down for NW-European pollinators and plants. Ecol. Lett. 16, $870-878$

Carvell, C. (2002) Habitat use and conservation of bumblebees (Bombus spp.) under different grassland management regimes. Biol. Conserv. 103, 33-49

Carvell, C., Westrich, P., Meek, W.R., Pywell, R.F., Nowakowski, M. (2006) Assessing the value of annual and perennial forage mixtures for bumblebees by direct observation and pollen analysis. Apidologie 37, 326340

Chapman, R.F. (2012) The insects: structure and function, 5 th edn. Cambridge University Press, USA

Cnaani, J., Thomson, J.D., Papaj, D.R. (2006) Flower choice and learning in foraging bumblebees: effects of variation in nectar volume and concentration. Ethology 112, 278-285

Cohen, A.C. (2004) Insect diets: science and technology. CRC Press, Boca Raton

Comba, L., Corbet, S.A., Hunt, L., Warren, B. (1999) Flowers, nectar and insect visits: evaluating British plant species for pollinator-friendly gardens. Ann. Bot. 83, 369-383

Connop, S., Hill, T., Steer, J., Shaw, P. (2010) The role of dietary breadth in national bumblebee (Bombus) declines: simple correlation? Biol. Conserv. 143, 27392746

Cook, S.M., Awmack, C.S., Murray, D.A., Williams, I.H. (2003) Are honey bees' foraging preferences affected by pollen amino acid composition? Ecol. Entomol. 28, 622-627

Corbet, S.A. (2003) Nectar sugar content: estimating standing crop and secretion rate in the field. Apidologie 34, $1-10$

Day, S., Beyer, R., Mercer, A., Odgen, S. (1990) The nutrient composition of honeybee-collected pollen in Otago, New Zealand. J. Apic. Res. 29, 138-146

De Groot, A.P. (1953) Protein and amino acid requirements of the honeybee (Apis mellifera L.). Physiol Comp Oecologia 3, 197-285

Dufrêne, M., Legendre, P. (1997) Species assemblages and indicator species: the need for a flexible asymmetrical approach. Ecol. Monogr. 67, 345-366

Erdtman, G. (1960) The acetolysis method. A revised description. Svensk Botanisk Tidskrift 54, 561-564

Fontaine, C., Collin, C.L., Dajoz, I. (2008) Generalist foraging of pollinators: diet expansion at high density. J. Ecol. 96, 1002-1010

Frankard, P., Ghiette, P., Hindryckx, M.-N., Schumacker, R., Wastiaux, C. (1998) Peatlands of Wallony (SBelgium). Suoseura - Finnish Peatland Society 49, 33-47

Génissel, A., Aupinel, P., Bressac, C., Tasei, J.-N., Chevrier, C. (2002) Influence of pollen origin on performance of Bombus terrestris micro-colonies. Entomol. Exp. Appl. 104, 329-336

Gibbs, J.P. (2000) Pérdida de Humedales y Conservación de la Biodiversidad. Conserv. Biol. 14, 314-317

Gonzalez-Teuber, M., Heil, M. (2009) Nectar chemistry is tailored for both attraction of mutualists and protection from exploiters. Plant Signal. Behav. 4, 809-813

Goslee, S., Urban, D. (2007) The ecodist package for dissimilarity-based analysis of ecological data. J. Stat. Softw. 22, 1-19 
Goulson, D. (2009) Bumblebees: behaviour, ecology, and conservation, 2nd edn. Oxford University Press, USA

Goulson, D., Darvill, B. (2004) Niche overlap and diet breadth in bumblebees: are rare species more specialized in their choice of flowers? Apidologie 35, 9

Goulson, D., Lye, G.C., Darvill, B. (2008) Decline and conservation of bumble bees. Annu. Rev. Entomol. 53, 191-208

Gruter, C., Ratnieks, F.L.W. (2011) Flower constancy in insect pollinators. Commun. Integr. Biol. 4, 633-636

Guillén, A., Rico, E., Castroviejo, S. (2005) Reproductive biology of the Iberian species of Potentilla L. (Rosaceae). Reprod. Biol. 62, 9-21

Hagbery, J., Nieh, J.C. (2012) Individual lifetime pollen and nectar foraging preferences in bumble bees. Naturwissenschaften 99, 821-832

Hanley, M.E., Franco, M., Pichon, S., Darvill, B., Goulson, D. (2008) Breeding system, pollinator choice and variation in pollen quality in British herbaceous plants. Funct. Ecol. 22, 592-598

Harder, L.D. (1986) Effects of nectar concentration and flower depth on flower handling efficiency of bumble bees. Oecologia 69, 309-315

Human, H., Nicolson, S.W., Strauss, K., Pirk, C.W.W., Dietemann, V. (2007) Influence of pollen quality on ovarian development in honeybee workers (Apis mellifera scutellata). J. Insect Physiol. 53, 649-655

Ishii, H.S. (2005) Analysis of bumblebee visitation sequences within single bouts: implication of the overstrike effect on short-term memory. Behav. Ecol. Sociobiol. 57, 599-610

Janson, E.M., Grebenok, R.J., Behmer, S.T., Abbot, P. (2009) Same host-plant, different sterols: variation in sterol metabolism in an insect herbivore community. J. Chem. Ecol. 35, 1309-1319

Juillet, N., Scopece, G. (2010) Does floral trait variability enhance reproductive success in deceptive orchids? Perspect. Plant Ecol. Evol. Syst. 12, 317-322

Kindt, R., Coe, R. (2005) Tree diversity analysis: a manual and software for common statistical methods for ecological and biodiversity studies. World Agroforestry Centre (ICRAF), Nairobi. ISBN 92-9059-179-X

Kitaoka, T.K., Nieh, J.C. (2009) Bumble bee pollen foraging regulation: role of pollen quality, storage levels, and odor. Behav. Ecol. Sociobiol. 63, 625-625

Kleijn, D., Raemakers, I. (2008) A retrospective analysis of pollen host plant use by stable and declining bumble bee species. Ecology 89, 1811-1823

Leonhardt, S.D., Blüthgen, N. (2012) The same, but different: pollen foraging in honeybee and bumblebee colonies. Apidologie 43, 449-464

Liao, K., Gituru, R.W., Guo, Y.-H., Wang, Q.-F. (2011) The presence of co-flowering species facilitates reproductive success of Pedicularis monbeigiana (Orobanchaceae) through variation in bumble-bee foraging behaviour. Ann. Bot. 108, 877-884
Lognay, G., Severin, M., Boenke, A., Wagstaffe, P.J. (1992) Edible fats and oils reference materials for sterols analysis with particular attention to cholesterol. Part 1. Investigation of some analytical aspects by experienced laboratories. Analyst 117, 1093-1097

Mayer, C., Michez, D., Chyzy, A., Brédat, E., Jacquemart, A.-L. (2012) The abundance and pollen foraging behaviour of bumble bees in relation to population size of whortleberry (Vaccinium uliginosum). PLoS ONE 7, e50353

Michener, C.D. (2007) The bees of the world. Johns Hopkins University Press, Baltimore

Nicolson, S.W. (2011) Bee food: the chemistry and nutritional value of nectar, pollen and mixtures of the two. Afr. Zool. 46, 197-204

Oksanen, J., Blanchet, F.G., Kindt, R., Legendre, P., Minchin, P.R., O'Hara, R.B., Simpson, G.L., Solymos, P., Stevens, M.H.H., Wagner, H. (2013) Vegan: Community Ecology Package. R package version 1.17-0. Available: http://CRAN.R-project.org/ package $=$ vegan

Ollerton, J., Winfree, R., Tarrant, S. (2011) How many flowering plants are pollinated by animals? Oikos 120, 321-326

Pelletier, L., McNeil, J.N. (2003) The effect of food supplementation on reproductive success in bumblebee field colonies. Oikos 103, 688-694

Percival, M.S. (1961) Types of nectar in Angiosperms. New Phytol. 60, 235-281

Proctor, M., Yeo, P., Lack, A. (1996) The natural history of pollination. Timber Press Inc., Oregon, USA

Prys-Jones, O.E., Corbet, S.A. (2011) Bumblebees: 6, 3rd edn. Pelagic Publishing, Exeter, England

R Development Core Team (2012) R: a language and environment for statistical computing. R Foundation for Statistical Computing, Vienna. [WWW Document]. URL http://www.R-project.org

Raguso, R.A. (2004) Flowers as sensory billboards: progress towards an integrated understanding of floral advertisement. Curr. Opin. Plant Biol. 7, 434-440

Rasmont, P., Regali, A., Ings, T.C., Lognay, G., Baudart, E., Marlier, M., Delcarte, E., Viville, P., Marot, C., Falmagne, P., Verhaeghe, J.-C., Chittka, L. (2005) Analysis of pollen and nectar of Arbutus unedo as a food source for Bombus terrestris (Hymenoptera: Apidae). J. Econ. Entomol. 98, 656-663

Roberts, D.W. (2012) labdsv: Ordination and Multivariate Analysis for Ecology. R package version 1.4-1. Available: http://CRAN.R-project.org/package=labdsv

Robertson, A.W., Mountjoy, C., Faulkner, B.E., Roberts, M.V., Macnair, M.R. (1999) Bumble bee selection of Mimulus guttatus flowers: the effects of pollen quality and reward depletion. Ecology 80, 2594-2606

Roulston, T.H., Cane, J.H. (2000) Pollen nutritional content and digestibility for animals. Plant Syst. Evol. 222, 187-209

Roulston, T.H., Cane, J.H., Buchmann, S.L. (2000) What governs protein content of pollen: pollinator 
preferences, pollen-pistil interactions, or phylogeny? Ecol. Monogr. 70, 617-643

Roulston, T.H., Goodell, K. (2011) The Role of Resources and Risks in Regulating Wild Bee Populations. Annu. Rev. Entomol. 56, 293-312

Schlindwein, C., Wittmann, D., Martins, C.F., Hamm, A., Siqueira, J.A., Schiffler, D., Machado, I.C. (2005) Pollination of Campanula rapunculus L. (Campanulaceae): how much pollen flows into pollination and into reproduction of oligolectic pollinators? Plant Syst. Evol. 250, 147-156

Sedivy, C., Müller, A., Dorn, S. (2011) Closely related pollen generalist bees differ in their ability to develop on the same pollen diet: evidence for physiological adaptations to digest pollen. Funct. Ecol. 25, 718-725

Somme, L., Mayer, C., Jacquemart, A.-L. (2014) Multilevel spatial structure impacts on the pollination services of Comarum palustre (Rosaceae). PLoS ONE 9, e99295

Southwick, E.E., Loper, G.M., Sadwick, S.E. (1981) Nectar production, composition, energetics and pollinator attractiveness in spring flowers of Western New York. Am. J. Bot. 68, 994-1002

Sowig, P. (1989) Effects of flowering plant's patch size on species composition of pollinator communities, foraging strategies, and resource partitioning in bumblebees (Hymenoptera: Apidae). Oecologia 78, 550-558

Standifer, L.N., McCaughey, W.F., Dixon, S.E., Gilliam, M., Loper, G.M. (1980) Biochemistry and microbiology of pollen collected by honey bees (Apis mellifera L.) from almond, Prunus dulcis. II. Protein, amino acids and enzymes. Apidologie 11, 163-171

Stout, J.C., Goulson, D. (2002) The influence of nectar secretion rates on the responses of bumblebees (Bombus spp.) to previously visited flowers. Behav. Ecol. Sociobiol. 52, 239-246
Svoboda, J.A., Thompson, M.J., Herbert, E.W., Shimanuki, H. (1980) Sterol utilization in honey bees fed a synthetic diet: analysis of prepupal sterols. J. Insect Physiol. 26, 291-294

Tasei, J.-N., Aupinel, P. (2008) Nutritive value of 15 single pollens and pollen mixes tested on larvae produced by bumblebee workers (Bombus terrestris, Hymenoptera: Apidae). Apidologie 39, 397-409

Vanderplanck, M., Leroy, B., Wathelet, B., Wattiez, R., Michez, D. (2014a) Standardized protocol to evaluate pollen polypeptides as bee food source. Apidologie 45, 192-204

Vanderplanck, M., Michez, D., Vancraenenbroeck, S., Lognay, G. (2011) Micro-quantitative method for analysis of sterol levels in honeybees and their pollen loads. Anal. Lett. 44, 1807-1820

Vanderplanck, M., Moerman, R., Rasmont, P., Lognay, G., Wathelet, B., Wattiez, R., Michez, D. (2014b) How does pollen chemistry impact development and feeding behaviour of polylectic bees? PLoS ONE 9, e86209

Verté, P. (2007) Les marais de la Haute-Semois, 40 années de conservation d'un site de très grand intérêt biologique. Echo des Réserves 3, 4-9

Waser, N.M. (1986) Flower constancy: definition, cause, and measurement. Am. Nat. 127, 593-603

Waser, N.M., Ollerton, J. (2006) Plant-pollinator interactions: from specialization to generalization. University of Chicago Press, Chicago

Waters, J., Darvill, B., Lye, G.C., Goulson, D. (2011) Niche differentiation of a cryptic bumblebee complex in the Western Isles of Scotland. Insect Conserv. Divers. 4, 46-52

Weiner, C.N., Hilpert, A., Werner, M., Linsenmair, K.E., Blüthgen, N. (2010) Pollen amino acids and flower specialisation in solitary bees. Apidologie 41, 476-487 